\title{
リパーゼ反応による油脂およびエステルの合成と変換
}

\author{
山 根 恒 夫 \\ (名古屋大学農学部)
}

\section{1. リパーゼの触媒反応の分類}

リパーゼは，いうまでもなく、トリグリセりドを加水 分解してグリセリンと脂肪酸にする䣼素で西り, triacylglycerol acylhydrolase, E.C.3.1.1.3 と命名されてい る.しかし，この反応以外に種々の反応を触媒すること がわかってきた，現在知られているりパーゼの触媒反応 を分類すると図1のよ5になる．エステルの加水分解は 本来の触媒反応である。この分野でも，油脂の加水分解 や、エステルの立体特異的水解など，工業的に重要な反 応があるが，このレビニ一は合成と变換を中心にしてい るので，述べないことにする，リパーゼの触媒作用は可 逆的であり，微水系では，エステルの合成を触媒する.

リパーゼの触媒作用て興味樑いのは, エステル転移であ る. 油脂工業で付加価値の高い変換反灾としては, エス テルの加水分解よりも，エステル合成やエステル転移が 上り重要であるう。一般にエステル結合の加水分解の自 由エネルギーはきわめて低く、またエステル転移の総自 由エネルギーは零であるから，エステル転移は容易に起 こる、リパーゼによるエステル䎐移反応は，エステルと 反応する相手の化学種によって，図1のように，4つに 細分類される.これら 4 タイプの反応をまとめて, 'エ ステル交换 (interesterification)’ と呼ぶ研究者もある が，生化学では，官能基の転移は，trans一と呼ばれてい る(たと兊ば, transglycosylation, transpeptidylation, transphosphatidylation など)ので, 'interesterification' より 'transesterification' のほらが適切であると思う. したがって,このレビューでは,ェステル交換 (interesterification) はタイブ3.3の反応に対してのみよぶこと にする. 以下，図 1 の分類の順に，まずェステル合成の

$\dagger$ Synthesis and Conversion of Fats and Esters by Lipase-catalyzed Reactions.

Tsuneo YAMANE (Department of Food Science and Technology, Faculty of Agriculture, Nagoya University, Chikusa-ku, Nagoya 464)
うち興味深い反応を紹介し，炊にェステル転移の最近の 研究を紹介する.

\section{2. エステル合成}

微水系で，リパーゼにより，エステルが収率上く合成 できる.この分野の研究は多い，著者らは，膜型バイオ リアクターを用いて脂肪酸とグリセリンよりグリセりド の連続合成を試みだ(1,2)，得られた油脂は，モノダリセ リドとジグセりドとトリグリセりドの混合物であった。 食品用乳化剂として多量に使われているモノグリセリド

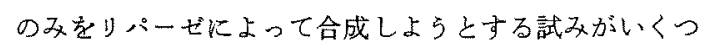
かある. Penicillium cyclopium のりパーゼにより, 脂肪 酸とグリセりンから，モノグリセりドのみが生成するこ とが報告されている(3). また，グリ七リドをあらかしめ アセトンと反応させアセタールとし，これと脂肪酸とを リパーゼにより反応させてできるニノエステルを，加水 分解してアセトンをはずすと，棌収率 $100 \%$ でモノグ リ七リドが得られる(4,5).この場合, 脂肪酸とらりせリ ンのアセタールがよく混和し均一相となる利点がある.

糖と脂肪酸のエステルであるシニガーェステルす食品 用乳化剂として多用されている。リペーゼによりシュガ 一エステルが合成される(6,7). ショ糖は水酸基を多く持 っているので, ニステルの混和物が得られる.

キラルな脂肪酸あるいはキラルなアルコールを用い て, リバーゼがどの程度立体特異的エステル合成を触媒 するか㤯味深いテーマであるが，いくつかのリパーゼ は立体特異性を示吉(8). axial chirality を調べた研究も 苏年

3. アシドリシス $(10)$

この反応で，現在，最も興味が持たれているのは，安 価な油脂からカカオ代替脂を合成する反応である、製果 用（主としてチョコレート）の原料として，油脂のなか では最も高価なカカオ脂は，1，3 位住飽和脂肪酸でする パミチン酸あるいはステフリン酸を，2位に不飽和脂 肪酸であるオレイン酸を持つ対称性トリグリセリドであ 


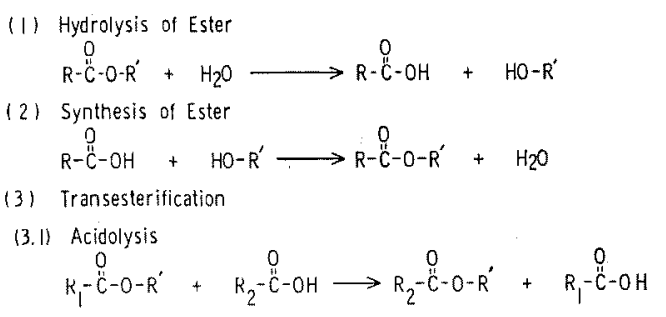

(3.2) Alcoholysis $R-\stackrel{O}{C}-0-R_{1}^{\prime}+H O-R_{2}^{\prime} \longrightarrow R-C^{\prime \prime}-0-R_{2}^{\prime}+H O-R_{1}^{\prime}$

(3.3) Ester Exchange (Interesterification) $R_{1}-{ }^{\prime \prime C}-0-R_{1}^{\prime}+R_{2}-\ddot{C}-0-R_{2}^{\prime} \rightarrow R_{1}-\dot{C}-0-R_{2}^{\prime}+R_{2}-\ddot{C}-0-R_{1}^{\prime}$ (3.4) Aminolysis

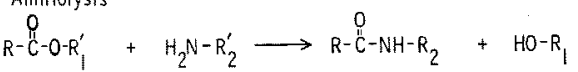

図 1 yパーゼが触媒する反応の分類

る、そこで, 安洒な油脂と脂肪酸に $1 ， 3$ 位特異性りパ 一ゼを作用させてカカオ脂様油脂を製造する研究が多数 報告されている，原料油脂としては，パーム油中間区分 が使用され，脂肪酸としては，ステアリン酸，パミチ ン酸が使用され，リパーゼとしては，Rhizopus delemar, Rhizopus niveus, Rhizopus chinensis, Mucor miehei 由来のリパーゼが用いられている.醅素の使用形態 は,

（1）酵素を適当な担体に吸着固定化し，カラムに充 垻する方法 (醭素法) (11)

（2）䤃素活性を有する乾燥菌体（微小量の水を含 む）を適当な担体に保持し，カラムに充鰿する方法（菌 体法) ${ }^{(12)}$

の 2 通りの方法がある、また，反応液としては，

（1）へキサンに油脂㓡よび脂肪酸（あるいは脂肪酸 エステル）を溶解して用いる方法（溶媒法）

（2）高温 $\left(60^{\circ} \sim 65^{\circ} \mathrm{C}\right)$ にして，油脂と飽和脂肪酸 を夜状区融解して行ら力法 (無溶媒法)

が知られている。この分野では最も技術が進んでいると 思初れるニニリパー社では，，ボ社の固定化りパーゼを 用い無溶媒法で企業化しようとしているよ5である。 た，脂肪酸の低級了ルコールエステルと油脂の反応（分 類としてはタイプ 3.3 の反応に入る)による称性トリグ リヒリドの合成もよく研究されている，脂肪酸エステル にすると，人キ甘ン中の溶解度が增大するといらメリッ トも㐫る.力カ才脂様油脂合成反応のも51つの重要な 点は，ジ゙りセりドを生成する加水分解反応の抑制であ

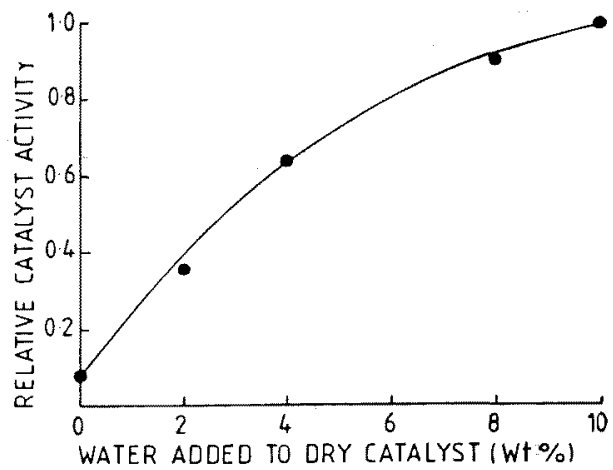

图 2 Aspergillus niger リパーゼと Hyflo Supercel（セライトの一種）から調製した触媒の アシドリシス反応に及ぼす水分棌加の影響(10)

る、図 2 にみられるよらに，転移活性は办分が多い泀ど 高いが，加水分解反店を抑えるためには，水分をできる だけ少なくしなり机ばならず，最適水分は両者の变協に より決めざるをない。

\section{4. アルコホリシス}

著者らは，アルコホリシスの一種であるグリセロリシ ス（油脂とグリセリンとの反応）について研究してい る、ます，種々の岍生物起源のリパーゼのグリセロリシ 不活性を調へ，比較的反応性が高く，乙かる入手が容易 な, Pseudomonas fuorescens 起源のリパーゼについて 詳しく実験した(13\}。このりパーゼによる油脂のグリセロ

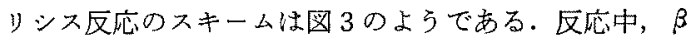
位のエステルの $\alpha$ 位への非酵素的アシル基転移が起こ る.この反応に及ばす一番大きな影䅉因子は，グリセリ ン中の水分である(図 4 ). 次に，著者らが開発した微孔 性薄膜型バイオりアクターを用いた連続グリセロリシス 反応を実施し，酵素の操作安定性を調べ，約 3 週間であ

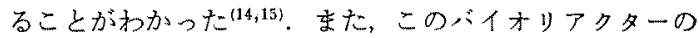
スタールアップについても研究した ${ }^{(16)}$.この反応では, モノグリセリド 10〜20\%,ジグリセりド 35〜 45\%, 未反 応のトリグリセりド55 35\% のグリセりド混合物が得 られ，遊離脂肪酸が活とんど含まれないのが特色であ り,この生成物は機能性油脂としての用途がありそうて ある.グリ七ロリシス反応は乾燥菌体です起こる(17)。 $\omega$ ヒビロキシルカルボン酸のカルボキシル基をメチ ルエステルにした化合物を基質にすると，リパーゼによ るラクトン化反灾（分子内エステル化）が起こる(18)。こ れも， $\mathrm{OH}$ 基とェステルとの間の反応といら観点からす るとアルコホリシスの一種である。生成物は，たとえ 


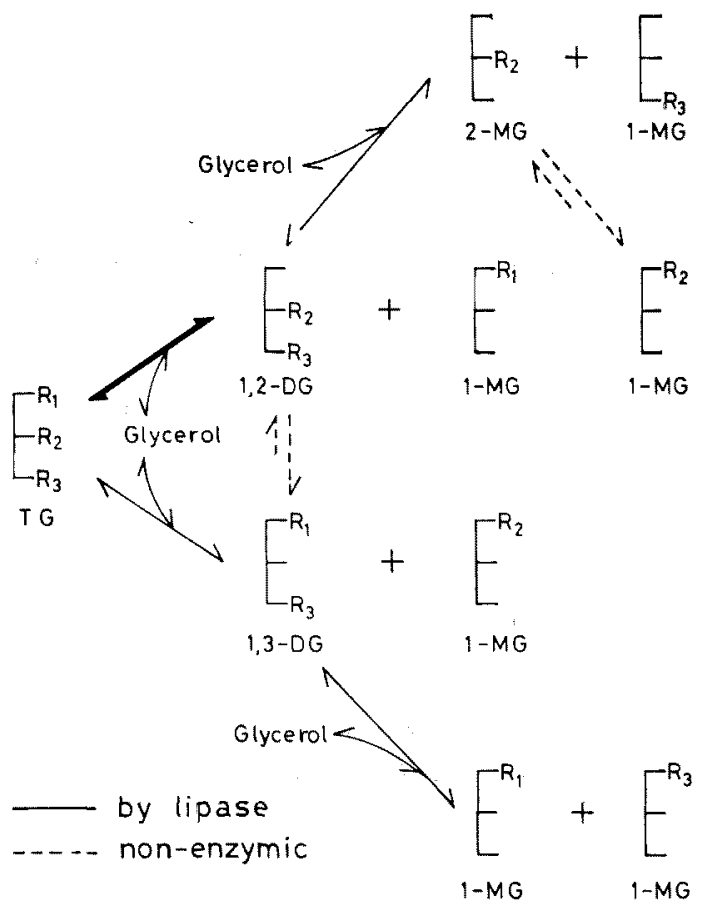

図 3 Pseudomonas fuorescens リパ-ビによる 油脂のグリ七ロリシスの想定スキーム(13)

ば，シクロペンタデカノリドであり，合成ムスクとして 有益な化合物である。

\section{5. エステル交換}

位監特異性のないリパーゼを用いると，化学的エステ ル交換と同㥞にランダムな油脂のエステル交換が起こ る。たと光ば，Candida cylindracea のリパーゼを用い てココナッ油さオリーブ油との間でェステル交換を行う と，アルカリ金属を触媒とした化学的エステル交换を行 ったものと同じトリグリセりト組成を持つ油脂が得られ る(19)．位置特異性のある Mucar miehei のリバーどを 用いて大豆油と牛脂のエステル交換を実施すると，両者 の単なる泿合物より融点特珄の異なる油脂が得られる. これらの油脂は、マーガリン用油脂としての用途がある よ5た。

\section{6. アミノリシス}

このタイプの反応例は非常に少ない.へキサン中で,

豚脺臟リパービによるィチル酪酸とブヂランンとの反 応 ${ }^{(20)}$ 和よび Candida cylindracea のリパーゼによるぺ プチド類の合成 ${ }^{(21)}$ ，が知られている，将来，微水系でつ ミノ酸のペプチド類がリパーゼにより合成される可能性 がある(22).

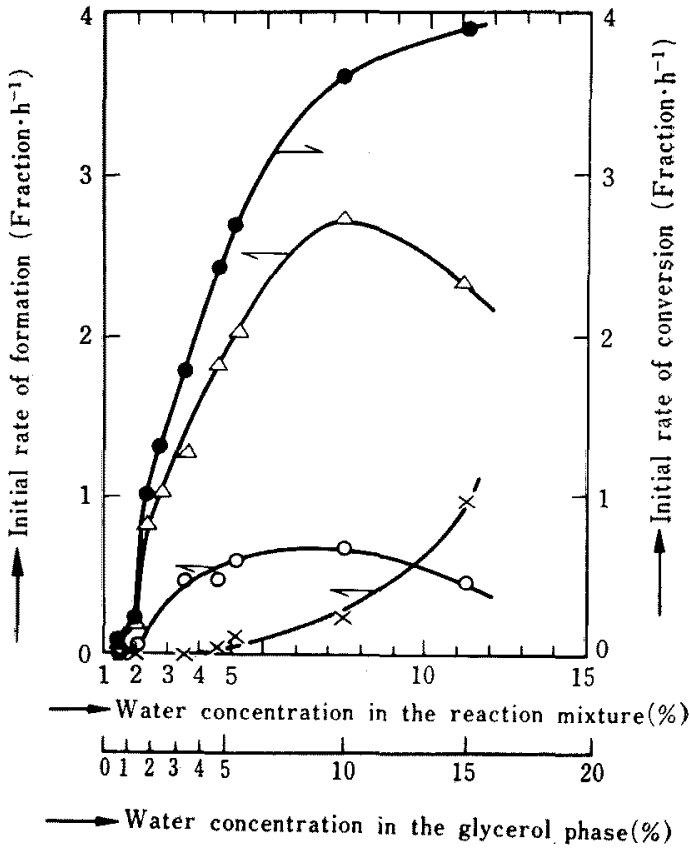

図 4 Pseudomonas fuorescens リパーゼによるグ リ七ロリシスの初速度に及ぼす水分の影響(13) 一○一, 全モノグリセリド; 一- - 全ジグリセ リド;一×一, 遊離脂肪酸; 一一一, 反灾率

7.おおりに

本来の触媒作用である酒脂の加水分解以外に，リパー ぜは、エステル結合に関連する種々の合成・変換反応を 触媒することがわかってきたが，リパーゼのコストが高 いので，工業的に韦施されそちなプロ七スは少ない、今 後，リパーゼでなりればなしえない高付加洒值物質合成 の一層の追求，およびリパーピ生産コストの低減が望ま れる、また，合成反応やエステル転移反応はいずれも微 水系で実施されるので，反応系に拈ける徽水分の最適制 御といら酵素工学的技術を確立せるばならない、(23).

(1) M. M. Hoq, T. Yamane and S. Shimizu : $J$. Am. Oil Chem. Soc., 61, 776 (1984).

(2) M. M. Hoq, H. Tagami, T. Yamane and S. Shimizu: Agric. Biol. Chem., 49, 335 (1985).

（3）山口庄太郎，松宮祐子，間瀬民生：日本農芸化 学昭和 60 年度会大会, 講演要旨集, $1985, p$. 452 .

(4) S. E. Godtfredsen : Abstract of 5 th International Symposium on the Life Sciences, 1986 , p. 13.

（5）佐伯尚史, 西尾尚道, 永井史郎：昭和 62 年度 
日本酸醋工学会大会講演要旨集, 1986, p. 27.

(6) H. Seino, T. Uchibori, T. Nishitani and S. Inamasu: J. Am. Oil Chem. Soc, 61, 1761 (1984).

（7）中田博之，神野和人，“近澤弥生，森田，勇，西 尾尚道, 林 光則, 永井史郎：昭和 61 年度日 本酸醉工学全大会講演要旨集, 1986, p. 87 .

(8) S. Koshiro, K. Sonomoto, A. Tanaka and S. Fukui : J. Biotechnol,, 2, 47 (1985).

(9) G. Gil, E. Ferre, A. Meou, J. L. Petit and C. Triantaphylides: Tetrahedron Lett., 28, 1647 (1987).

(10) A. R. Macrea: "Biocatalysis in Organic Synthesis," ed. by J. Tramper, H.C. Van Derplas and P. Linko, Elsevier, 1985, p. 195.

(11) R. A. Wisdom, P. Dunnill and M. D. Lilly : Biotechnol. Bioeng., 29, 1081 (1987).

(12) S. Kyotani, H. Fukuda, H. Morikawa and T. Yamane: J. Ferment. Technol., 66, 71 (1987).

(13) T. Yamane, M. M. Hoq, S. Itoh and S. Shimizu :J. Jpn. Oil Chem. Soc., 35, 625 (1986).
(14) T. Yamane, M. M. Hoq, S. Itoh and S. Shimizu: J, Jpn. Oil Chem. Soc, 35, 52 (1986).

(15) T. Yamane, J.S. Rhee, Y. Ohta and S. Shimizu : J. Jpn. Oil Chem. Soc., 36, 474 (1987).

(16) Y. Koizumi, K. Mukai, K. Murakawa and T. Yamane: $J$. Jpn. Oil Chem. Soc., 36, 561 (1987).

（17）壇计雅彦，太田安英：昭和 61 年度日本酸酵工 学食大会要旨集, 1986, p.53.

(18) A. Makita, T. Nihira and Y. Yamada: Te. trahedron Lett., 28, 805 (1987).

(19) A. R. Macrea : J. Am. Oil Chem. Soc., 60, 291 (1983).

(20) A.Zaks and A.M. Klibanov: Proc. Natl. Acad. Sci, 82, 3192 (1985).

(21) J. R. Matos, J.B. West and C.-H. Wong : Biotechnol. Lett., 9, 233 (1987).

(22) A. L. Margolin and A. M. Klibanov : J. Am. Chem. Soc., 109, 3802 (1987).

(23) T. Yamane: J. Am. Oil Chem. Soc., 64, 1647 (1987). 